\title{
Reforming an insider-outsider labor market: the Spanish experience
}

\author{
Samuel Bentolila1, Juan J Dolado ${ }^{2 *}$ and Juan F Jimeno ${ }^{3}$
}

\author{
*Correspondence: \\ dolado@eco.uc3m.es \\ 2 Universidad Carlos III, Calle Madrid \\ 126. 28903 Getafe, Spain \\ Full list of author information is \\ available at the end of the article
}

\begin{abstract}
This paper presents a case study on reforming a very dysfunctional labor market with a deep insider-outsider divide, namely the Spanish case. We show how a dual market, with permanent and temporary employees, makes real reform much harder, and leads to purely marginal changes that do not alter the fundamental features of labour market institutions. While the Great Recession and the start of the sovereign debt crisis have lately triggered two labor reforms, the political economy equilibrium has not allowed them to be transformational enough.
\end{abstract}

JEL codes: H29, J23, J38, J41, J64

Keywords: Temporary contracts, Dualism, Labor market reform, Political economy, Great recession

\section{Introduction}

Since the early 1980s, the world economy has been subject to the twin forces of growing globalization and accelerated technological progress. European countries have tried to adapt labor market institutions to this changing environment in different ways. In several cases, the strategy has been to introduce labor market flexibility at the margin, by widening the scope of so-called atypical employment, through temporary and part-time contracts. This, together with the high rates of unionization or coverage of collective bargaining prevailing in these countries, has exacerbated the insider-outsider divide in their labor markets. Notice that the latter term comes originally from the standard insideroutsider model, which explains how persistent unemployment can arise when working conditions, and wages in particular, are determined by taking into account only the interests of employed insiders, thus disregarding the interests of unemployed outsiders (Lindbeck and Snower 1984,1988; Blanchard and Summers 1986). Yet, in the specific context of dual/segmented labor markets, this conventional interpretation should be slightly modified. In line with the literature on this topic, not all employed workers should be considered as being insiders but only those who hold open-ended or permanent labor contracts subject to high employment protection (Bentolila and Dolado 1994; SaintPaul 1996). Conversely, employees under very flexible contracts are better thought of as being part of the outsiders because, given that their role is precisely to bear the brunt of employment adjustments, their attachment to the job is fragile.

(c) 2012 Bentolila et al.; licensee Springer. This is an Open Access article distributed under the terms of the Creative Commons Attribution License (http://creativecommons.org/licenses/by/2.0), which permits unrestricted use, distribution, and reproduction in any medium, provided the original work is properly cited. 
Though in most instances the introduction of flexibility at the margin was perceived as a transitory measure aimed at counteracting the negative employment consequences of recessions during the early 1980s and early 1990s, the incidence of atypical employment has continuously increased: in 1980 the temporary employment rate among employees in Europe was around 7.5\%, now it is around 14\%, reaching maximum values in Portugal (23\%) and Spain (25\%).

The expansion of 1995-2006 drew attention away from unemployment, but the impact of the financial crisis, the employment consequences of the Great Recession, and the need for supply policies to promote long-term growth in Europe in the context of the European Monetary Union (EMU), have again shifted the focus towards new labor market reforms. While the drawbacks of atypical employment were blurred by the boom, its negative economic and social effects have become more salient with the recession, so that the need for a different type of labor market reform has become increasingly evident (International Monetary Fund 2010, Box 3.1; Boeri 2011 ). Given past experience, this time the dualism strategy is being challenged and some economists have started to explore new routes, which are geared towards making labor market regulation more efficient, flexible, and simple (Blanchard and Tirole 2003; Cahuc and Kramarz 2004; Boeri and Garibaldi 2008; Bentolila et al. 2008, Ichino et al. 2009; Andrés et al. 2009). Their proposals do, however, face the difficulty of eliminating an insider-outsider divide that, in some countries, has become well-entrenched. Its equilibrium nature stems from its being beneficial to particular groups of workers and employers, mostly represented by unions and employer associations with institutional recognition and political power.

In this paper we revisit the Spanish case. Starting from 1984, when the unemployment rate was close to $20 \%$, Spain has become a pioneer in the strategy of reforming the labor market at the margin -i.e., by liberalizing so-called atypical employment contracts-. Since then, after many labor market reforms that have modified the menu of hiring and firing conditions attached to temporary and permanent contracts, the unemployment rate has exhibited a very large volatility, having recently surged from $8 \%$ just before the crisis to about $25 \%$ nowadays. The experience of the last three decades provides a few interesting insights and very informative evidence on the socioeconomic consequences of and the political economy issues brought forth by dual labor markets. These are worth considering, not only for further labor market reform in Spain, but also for other countries, like France and Italy (See Boeri, 2011), that also followed the same two-tier reform strategy during the 1980s, and now also face the side effects of a dual labor market.

Thus, building upon the large body of evidence on labor reforms, we discuss the Spanish labor market performance during the Great Recession (Section 2), highlight the main institutional idiosyncrasies that give rise to an extreme insider-outsider divide in its labor market (Section 3), address some key elements of the political economy of labor market reforms (Section 4), describe and assess (negatively) the first two Spanish labor market reforms undertaken in the midst of the crisis (Section 5), and review a few recent proposals for reform (Section 6). We conclude (Section 7) with some comments on the priority that labor reforms should have in the program of structural reforms that the Spanish economy urgently needs at the current juncture. Since, after writing this paper, another reform has been passed in February 2012, this time by the new conservative Government, we also add at the end of this section a brief discussion of its main features and its pros and cons in the light of the previous proposals. 


\section{Labor market performance in the Great Recession}

During last few decades, the Spanish labor market has shown clear signs of a dysfunctional performance. The unemployment rate in Spain has not only been permanently among the highest in the OECD, but it has also experienced staggering swings: as Figure 1 illustrates, starting from around 5\% in 1978, the (OECD harmonized) unemployment rate reached a peak above $17 \%$ in 1985, fell back to around $13 \%$ in 1990, only to shoot up again to 20\% in 1994. During the long expansion of 1995-2006, it decreased to 8\% in 2007. Nowadays, after the huge employment impact of the financial crisis, it has risen close to a staggering $25 \%$. As shown in the graph, these are much wider fluctuations than those experienced by France, which is representative of the Eurozone average. The cyclical features of the Spanish labor market are also remarkable. Labor productivity and real wages are strongly countercyclical, in part due to employment composition effects derived from the high incidence of temporary contracts (Carrasco et al. 2011). The latter are typically associated to low-wage/productivity jobs which are easily created in expansions and quickly destroyed in downturns (Dolado et al. 2002; Bentolila et al. 2008). Moreover, despite high firing costs for permanent contracts, employment is highly volatile, even more than in countries with low labor adjustment costs (Costain et al. 2010).

Bentolila and Jimeno (2006) provided an explanation of the main factors behind the wild ride of the Spanish unemployment rate over the period 1976-2001. It relied mostly on the interaction between macroeconomic shocks and a set of exceptionally unemploymentprone institutions, in particular, employment protection legislation (EPL), unemployment benefits, and collective bargaining. These authors cautioned against interpreting the relatively low unemployment rates of the mid-2000s as a sign of a permanent decrease in structural unemployment and called for significant labor market reforms in the wake of the introduction of the euro.

From 2001 to 2007, two key factors supported employment growth. The first one was a significant expansion of credit, induced by the fall in interest rates that followed Spain's accession to EMU and, more broadly, by a pervasive relaxation in the conditions of

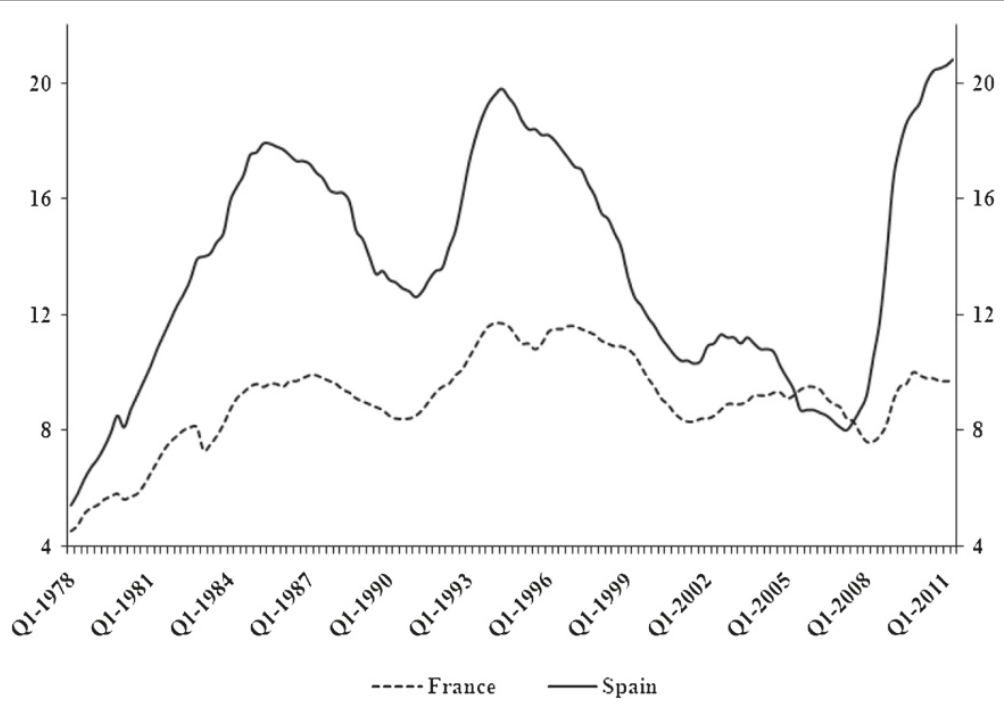

Figure 1 Unemployment rate in Spain and France (harmonised definitions, \%). 
access to credit. The second factor was a very large immigration inflow that, attracted by the growing specialization of the Spanish economy in low value added and highly labor-intensive industries (construction, tourism, personal services) as a result of the investment boom, has modified, to some extent, the demographic structure of the Spanish population. Growth could not be sustained indefinitely on the basis of these driving forces. Moreover, both labor and total factor productivity growth were very low, and important distortions in the domestic labor and product markets persisted, so that competitiveness deteriorated significantly. Together with the sharp increase in private sector indebtedness, this led to the Spanish economy being increasingly dependent on external financing (the current account deficit reached 10\% of GDP in 2007), a situation which made it especially vulnerable in the subsequent global financial crisis. Despite these weaknesses, the impact of the financial crisis in Spain was, at least initially, not larger than in other European Union (EU) countries. As illustrated in Figure 2, the cumulative decline in GDP during 2008Q2-2009Q2 was equal to 4.4\%, below the EU14 average (i.e. EU15 minus Spain).

The cross-country variation of the growth impact of the crisis is rooted in the nature of the preceding expansion and, hence, in the sectorial specialization when the crisis hit. In countries with high private sector indebtedness, housing was by far the largest component of household wealth (80\% of all assets in the Spanish case, see Banco de España December 2010) and a high share of productive resources were devoted to the construction industry. When a housing bust followed the housing boom, there was a large negative demand shock, derived from the loss of wealth, and also a negative supply shock, linked to the past accumulation of inputs in now highly unproductive industries. Hence, in these countries the financial crisis had significant and long-lasting effects on economic activity. By contrast, in countries where housing prices had not grown much, the sectoral allocation of resources was not distorted by credit conditions and households were not highly indebted. Therefore, the main impact of the crisis was only a temporary fall in aggregate demand, stemming from the significant reduction in exports that took place when,

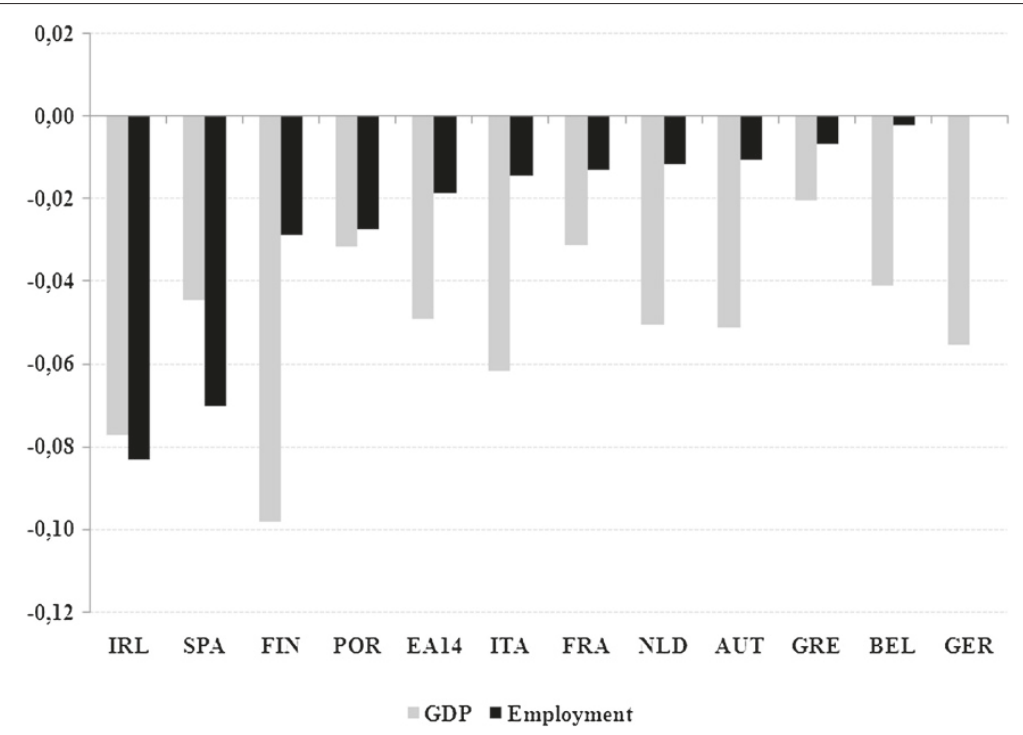

Figure 2 Fall in GDP and increase in the unemployment rate in selected countries (2008Q2-2009Q2). 
following the Lehman Brothers episode (15 September 2008), the financial crisis became systemic. Hence, these countries also had a significant fall in GDP, but it was apparently less persistent.

As is evident from Figure 2, during the 2008Q2-2009Q2 period, the cumulative GDP loss in Spain was much smaller than the employment loss, which was equal to $7 \%$, surpassed only by Ireland. It is often argued that the huge employment-GDP elasticity is due to large employment losses in the construction industry. Figure 3 shows that there is indeed a positive correlation between the housing price growth rate in 2000-2007 and the increase in the unemployment rate in 2007-2009, with three countries being clear outliers in this relationship, namely Ireland, Spain, and the US. Moreover, as revealed by Figure 4, the negative relationship between housing inflation and employment growth also holds when the construction industry is excluded. This evidence suggests that the main culprit for the large impact on employment must be found elsewhere.

In our search for alternative explanations, we can analyze the role of different factors underlying cross-country variation in the employment impact of the Great Recession. While the rise in unemployment has been largest in countries experiencing housing booms and external imbalances during the expansion (European Commission 2011), it is also true that the so-called Okun coefficient relating unemployment changes to output growth has recently been out of line with its historical values in many countries. Employment growth in Spain has been much lower and the rise of unemployment has been much larger than expected given the size of the output decline (Arpaia and Curci 2010).

To examine the Okun coefficient, it is useful to decompose the change in unemployment as follows. ${ }^{1}$ Given than $u \approx-\ln e$, where $u$ denotes the unemployment rate and $e$ the ratio of employment $(N)$ to the labor force $(L F)$, and that

$$
\Delta \ln N=\Delta \ln Y-\Delta \ln (Y / H)-\Delta \ln (H / N)
$$

where $H$ denotes working hours and $Y$ is GDP, we have the following approximate identity

$$
\Delta u \approx-\Delta \ln Y+\Delta \ln (Y / H)+\Delta \ln (H / N)+\Delta \ln (L F)
$$

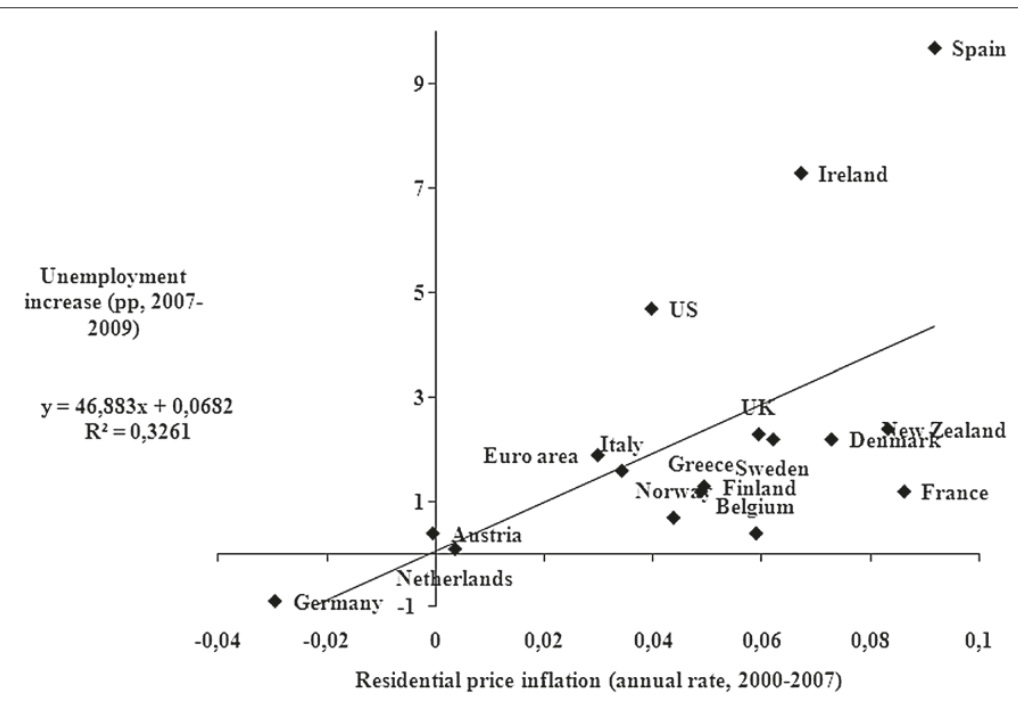

Figure 3 Unemployment change and residential price inflation in OECD countries. 


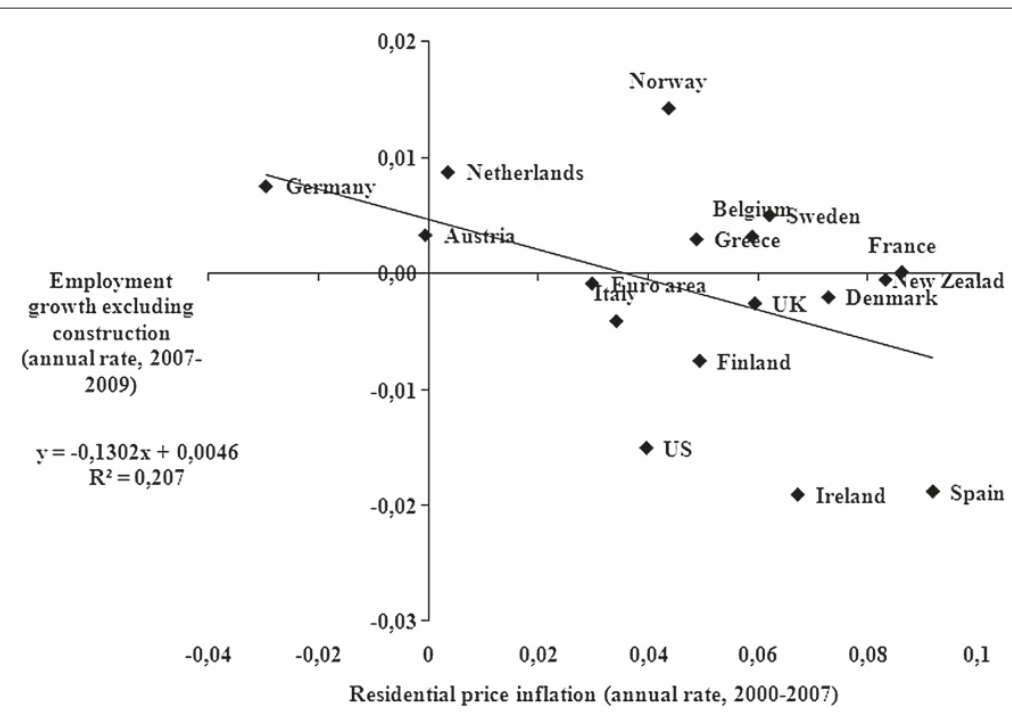

Figure 4 Employment growth (excluding construction) and residential price inflation in $\mathrm{OECD}$ countries.

Table 1 gives the figures corresponding to this breakdown during the first phase of the financial crisis (2008Q1-2009Q4) for the US, Germany, and Spain. According to the previous identity, the change in the unemployment rate (first row) is the sum of the growth rates of productivity per hour worked, hours per worker, and the labor force (rows 3 to 5) minus the growth rate of output (row 2). This decomposition reveals why the change in the Spanish unemployment rate during the period 2008-2009 has been twice as high as in the US. First, the output decline in Spain more than doubles that of the US. Moreover, increases in productivity, hours per worker, and the labor force have also pushed unemployment up. The rise in the labor force is, in contrast with the boom, not due to immigration but more likely to added worker effects (Casado et al. 2012). This evolution also contrasts Germany's, where a larger output decline coexisted with a fall in unemployment, due to reductions in labor productivity, hours per worker, and the labor force.

The fact that productivity is countercyclical and that wages and hours worked do not adjust in the aftermath of negative shocks to the Spanish economy are, to a large extent, the consequences of the institutional framework of the Spanish labor market, which we sketch in the following section.

Table 1 Accounting for changes in the unemployment rate during the Great Recession, 2008Q1-2009Q4 (\%)

\begin{tabular}{lcccc}
\hline & & US & Germany & Spain \\
\hline Unemployment rate & $\Delta u$ & 6.1 & -0.4 & 11.2 \\
Output & $\Delta Y / Y$ & -2.4 & -5.4 & -5.0 \\
Productivity & $\Delta(Y / H) /(Y / H)$ & 6.0 & -3.0 & 2.7 \\
Hours/worker & $\Delta(H / N) /(H / N)$ & -2.2 & -2.6 & 1.8 \\
Labor force & $\Delta L F / L F$ & -0.1 & -0.2 & 1.7 \\
\hline
\end{tabular}

Notes: Log-points. Data for the US and Germany are from Burda and Hunt (2011). For Spain, data are from the Quarterly National Accounts (www.ine.es). 


\section{An insider-outsider labor market}

The Spanish labor market is characterized by marked contractual dualism. In order to show how this situation came about, in this section we describe the main institutional features of EPL and collective bargaining in Spain, and then discuss the role of their interaction in generating an insider-outsider labor market.

\subsection{Employment protection legislation}

At the end of the Franco regime in late 1975, severance pay was very high, judicial protection was very stringent, unemployment insurance was very low and limited, and there was no collective bargaining. The main labor market institutions of the new democratic regime were established in the 1980 Workers' Statute which, in order to attract union support for a smooth political transition process, maintained the existing employment protection rules, extended and made more generous unemployment insurance, and introduced collective bargaining.

The dual approach to EPL in Spain started in 1984, when fixed-term contracts were liberalized, so that, at that time, firms could hire fixed-term employees subject a low severance pay (12 days' wages per year of service, hereafter p.y.o.s.) for any kind of $j o b$, with contract duration between 6 months and 3 years and compulsory conversion into permanent thereafter. As for permanent contracts, their conditions remained unchanged: workers were entitled to severance pay of 20 days' wages per year of service (with a maximum of 12 months' wages) in fair dismissals and to 45 days' wages p.y.o.s. (with a maximum of 42 months' wages) in unfair dismissals. Thus, there was a large gap in EPL between permanent and temporary jobs, collective dismissals required administrative approval (de facto not granted without an agreement with worker representatives), economic reasons for fair dismissals included in the law were quite limited, and labor courts usually made a very restrictive reading of those reasons. Moreover, constraints on internal flexibility, arising from regulations on geographic and functional mobility of employees were also strongly binding. It is therefore not surprising that soon after the reform almost all hires were conducted under fixed-term contracts and that the incidence of temporary work exceeded $30 \%$ of all employees in the early 1990s.

In view of this dramatic surge in temporary jobs, a long sequence of countervailing EPL reforms have subsequently taken place since 1994 so as to reduce their incidence. All of these reforms share, to some extent, two common features (see Bentolila et al. 2008). First, the conditions for the use of fixed-term contracts have been restricted, although temporary work agencies have been allowed to operate since 1994. Secondly, severance pay for permanent employees has been gradually and mildly reduced. This has been done through several measures. First, 1997 saw the creation of so-called employmentpromotion permanent contracts, entailing lower severance pay in case of unfair dismissal (33 days' wages p.y.o.s. with a maximum of 24 months' wages), yet targeted to specific groups of workers with lower employment opportunities and excluding most prime-age employees (30-44 years old). Second, in 2002, in case of unfair dismissal, firms were allowed to avoid going to court if they offered the penalty severance rate and the worker accepted it (thus avoiding also advance notice, interim wages, and uncertainty on the outcome in court). Then there was also a myriad of small changes in EPL throughout the period. 
On top of this, there have been significant rebates of social security contributions for firms either directly hiring with, or converting temporary into, permanent contracts. The rebates ranged from $40 \%$ to $60 \%$ during the first two years of contracts used to hire workers in some targeted groups (youth, long-term unemployed, and women underrepresented in some industries). However, since social security contributions are reduced only for a limited initial period (typically up to 3 years), it has been common for firms to fire workers as soon as the subsidy expires, so that separation rates shoot up for most groups of workers, especially over the first year. As a result, turnover in employment-promotion permanent contracts is much higher than in standard permanent contracts (García Pérez and Rebollo Sanz 2009).

Several labor market reforms (in 1994, 1997, 2002, and 2006) aimed at fighting the prevalence of temporary employment but they were not very successful since, by the mid-2000s, the temporary employment rate still remained very high (33.5\% of employees). A large number of contracts were being signed each year, more that 20 times the flow of net employment growth, and the conversion rate into open-ended contracts was very low, around $6 \%$ per annum. This churn generates an sizeable welfare loss due to the high uncertainty associated with temporary contracts, but it also creates a host of other negative effects.

Spain ranks very high in the well-known OECD EPL stringency measures for permanent (regular) contracts (which goes from 0 to 6), with a score of 3 for 2008, down from 3.9 in 1985-1993 (only surpassed by six countries out of thirty in 2008 and only by Portugal in the earlier period, see Venn, 2009). This index is computed on the basis of legal regulations corrected for their implementation. This is not the case for temporary contracts, where enforcement is ignored. Thus, Spain also ranks high in the EPL index for temporary contracts (the fourth highest in 2008). However, Bentolila et al. (2012) argue that lack of adjustment for enforcement, which is extremely weak in Spain, causes a substantial overestimation of the degree of stringency indicated by index. To address this problem, Madera (2012) has proposeds a new labor market duality index which consists of the sum of (i) the index of EPL for regular contracts times the complement of the EPL for temporary contracts (i.e. a measure of flexibility in temporary contracts) and (ii) a country-specific, time-varying underlying share of temporary jobs (net of demographics and other labor market institutions). This duality measure in Spain is by far the highest in a sample of twelve OECD countries. ${ }^{2}$

On the efficiency front, Spain has suffered for more than a decade of negative Total Factor Productivity (TFP) growth and this is partly related to the use of temporary contracts. Dolado et al. (2011) highlights the negative effect of the low conversion rate of temporary jobs into permanent jobs on worker effort, estimating it at around $20 \%$ of the slowdown in TFP in Spanish manufacturing firms over 1992 to 2005. This is consistent with the fact that, while $40 \%$ of permanent employees received training paid by their firms in 2006 (a pre-crisis year), only $23 \%$ of temporary employees did so. ${ }^{3}$

Last but not least, while temporary contracts were initially limited to younger workers, they are now widespread also among adults. Figure 5 shows that over the period 2005Q12007Q3 (the end of the boom) 80\% of workers aged 16-19 had a temporary contract, 32\% of workers in their thirties were still in temporary jobs, and also $24 \%$ of those in their forties. This profile is even flatter among the least skilled. In sum, temporary contracts have largely destroyed the expectations of a professional career for many Spanish workers. 


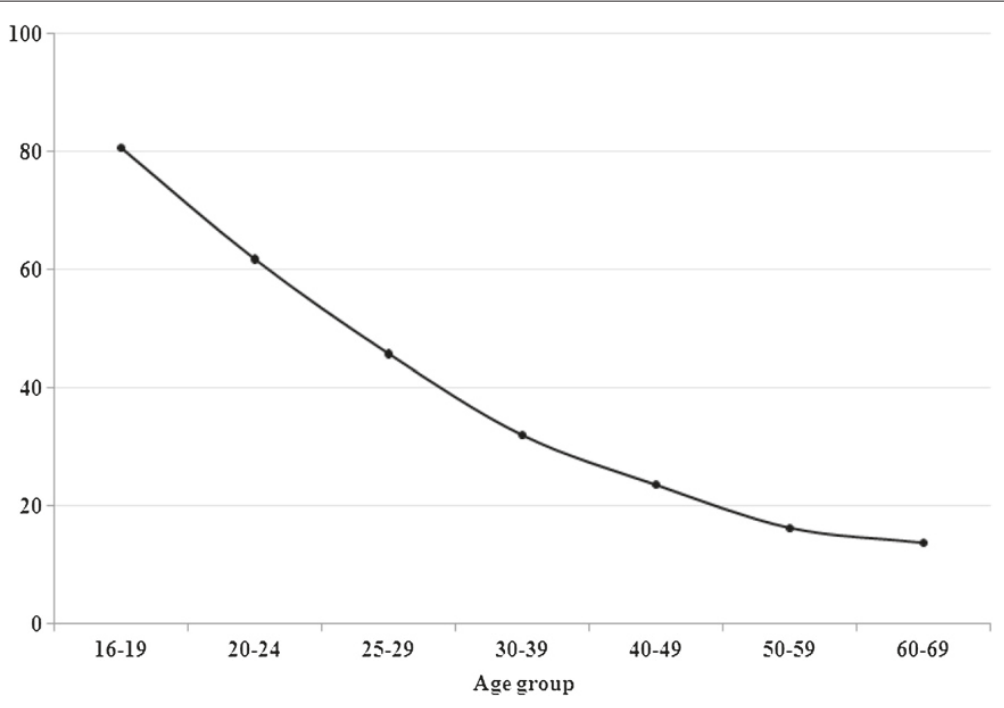

Figure 5 Temporary employment share by age group (2005Q1-2007Q3).

Since the peak in 2006Q3, at 34.6\%, there has been a substantial reduction in the temporary employment rate of about $10 \mathrm{pp}$. Part of this drop can be attributed to the huge destruction of temporary jobs in the construction industry, due to the bursting of the housing bubble since early 2008. In particular, from 2008Q1 to 2011Q2, 60\% of temporary jobs were lost in net terms $(650,000)$. As a reaction to the huge employment impact of the crisis, there has been another recent reform of EPL in 2010, which we discuss below. Summing up, despite all these countervailing reforms, the dual nature of EPL is still very pronounced in Spain and firms still find it more profitable to hire under fixed-term contracts, despite all the inefficiencies generated by a clearly excessive worker turnover.

\subsection{Collective bargaining}

Besides dual EPL, the social partners, i.e. labor unions and employers associations, support the insider-outsider model by exploiting collusion opportunities provided by the regulation of collective bargaining. This labor market institution exhibits the following features (see Visser 2011): (a) high coverage, around 80\% of workers, (b) an intermediate degree of coordination, with collective bargaining agreements being signed predominantly at the industry level though with some geographical decentralization (mostly at the province level), (c) erga omnes extension of collective bargaining agreements, namely, that they automatically apply to all workers and firms within their scope, (d) frequent wage indexation rules, applying to around $65 \%$ of employees, and (e) frequent social pacts between the major trade unions and employers' association, with some guidelines for wage increases.

As for unions, affiliation is very low in Spain, around 15-20\%, being larger in the public sector than in the private sector. Focusing only on the latter, there are large discrepancies according to contract type; for example, the affiliation rate is equal to $18.6 \%$ among permanent workers, but only of $7.8 \%$ among temporary workers. It also increases with age, going from $3 \%$ of permanent employees aged $16-24$ to $25.5 \%$ of those aged 55-64. 
A similar increase is observed with seniority and with firm size, from $7 \%$ of permanent employees at firms with 1-10 employees to $31.8 \%$ for those at firms over 250 employees (data for 2006 from Dolado et al., 2010).

There is little incentive for workers to become affiliated to labor unions, since industrywide collective agreements are extended to all workers regardless of affiliation status (see below). The relative power of different unions depends on the legal regulation of worker representation. Worker representatives are chosen in firm-level elections, which take place every four years in establishments above 5 employees. Labor unions surpassing $10 \%$ of the total number of worker representatives in a given industry (or $15 \%$ in a given region) obtain the status of being "highly representative", which allows them to participate in all bargains in the relevant domain. There are only two labor unions with such representative status at the national level, Comisiones Obreras (CCOO) and Unión General de Trabajadores (UGT), though other smaller unions also attain that status in specific industries or regions.

Given their low affiliation, labor unions obtain a very small share of their income from members. There is little information on union sources of funding, but most of it comes from the public sector. The two main unions receive funds from the national government for their worker representation activities, their participation in official bodies, and their involvement in training activities. According to one newspaper, over the period 2008-2011 labor unions received around 1 billion euros (0.03\% of GDP per year) from the central government. ${ }^{4}$ Regional governments also channel funds to unions for their involvement in accident prevention, worker placement, and training. Lastly, unions also obtain funds by charging non-affiliated workers for their services (e.g. in bargaining about collective dismissals).

How representative are labor unions? This issue is related to the restrictions on participation in firm-level elections. In particular, elections in establishments up to 5 employees are forbidden, and neither those employed with the firm for less than one month nor those on lease from temporary work agencies can vote, nor can the unemployed either. According to Dolado et al. (2010) in 2007 these criteria excluded around 30\% of all employees and, in particular, $41 \%$ of workers aged 16 to 24 .

As to employer associations, there is a national one, the Confederación Española de Organizaciones Empresariales (CEOE), which is in fact a confederation of 230 federations (175 are industry-specific and 55 are territorial), which themselves incorporate more than 5,000 organizations comprising around 1.45 million firms and entrepreneurs. Though there exists an associated confederation of small and medium-sized firms (Confederació $n$ Española de la Pequeña y Mediana Empresa, CEPYME), CEOE is essentially run by large companies. Like with labor unions, little information is available on its funding; some comes from its member organizations and another part from their involvement in official bodies and training activities.

The institutional setting of collective bargaining reinforces the dual nature of the Spanish labor market. With representation being mostly at the industry level, the major trade unions are able to bargain on wages for the whole economy. On the firms' side, employer representatives also use collective bargaining agreements to regulate competition, by imposing wage and employment conditions on all firms, regardless of the proportion of firms represented in the bargaining unit. As a result, bargained wages do not react much to changes in firm-specific productivity, while, due to the prevalence of 
wage indexation rules, they quickly adjust to inflation increases. As a result, real wages -and relative wages across industries- are very rigid.

\subsection{Interactions between EPL and collective bargaining}

The Spanish labor market stands out as an extreme case of a dual labor market in which the insider-outsider divide is very pronounced. There are two fundamental reasons. The first one lies with some peculiarities of employment protection legislation, which induces a very high incidence of fixed-term jobs and a concentration of worker turnover in particular segments of the labor market. The second is the automatic extension of collective bargaining agreements to all firms, regardless of the representativeness of the employer confederation signing the agreement and the economic and financial situation of the firms affected. This gives rise to both two types of workers and two types of firms.

Firstly, workers employed under standard (full-time, open-ended) contracts are subject to high firing cost and are covered by collective bargaining agreements that protect wages and working conditions against inflation and adverse productivity shocks. By contrast, workers under fixed-term contracts (among which youths, women, and low-skill workers are overrepresented) can be easily dismissed, thus suffering the main burden of the adjustment to productivity or demand shocks. As previously discussed, this situation stems from the high stringency of EPL for regular contracts and the non-enforcement of the regulation on temporary contracts. Regarding firms, large and high-productivity firms are less constrained by these regulations, as for them firm-level bargaining is easier to attain and wage levels are often above industry-level collective agreement floors. At the same time they can use these levels as a barrier to entry and an instrument to reduce competition from smaller companies. Small and low-productivity firms are much more constrained by industry-level collective bargaining, and therefore their growth prospects are more limited.

Insider-outsider models of unemployment associate insiders with employees and outsiders with the unemployed, but in a two-tier labor market this partition is not right, since temporary workers have little employment protection and therefore suffer high turnover. As a result, they typically have a weak attachment to each individual firm, so that their interests are neglected by permanent employees. Therefore, it is actually the interaction between the collective bargaining regulation and the dual nature of EPL that affords unions and employer confederations very powerful instruments to sustain the insideroutsider divide. For example, Jimeno and Toharia (1996) found that incentives to exert effort and avoid absenteeism were relatively higher for temporary workers who, given their very low firing costs, feel the threat of dismissal much more than permanent workers. And Bentolila and Dolado (1994) found that, using temporary workers as a buffer against employment destruction, insiders can increase their wages without putting their jobs at risk.

Many studies on wage dynamics have found that nominal wage growth in industrywide agreements is essentially determined by inflation, and, on the other hand, that wages hardly respond to productivity changes and only very mildly to changes in unemployment. ${ }^{5}$ Thus, massive employment losses during the Great Recession, since they have fallen to a large extent on temporary workers, have not triggered much wage moderation. 


\section{The political economy of labor market reform}

Structural reforms are usually hard to carry out. The reason is that there always exist population groups that are negatively affected by reforms and thus try to block or soften them. As a result, reforms require some political majority and certain economic conditions to materialize (Saint-Paul 2000). The last pre-Great Recession major labor market reform in Spain took place in 1997, with an isolated -but eventually important- reform in 2002. This is not so surprising, since the boom lasted from 1997 to 2007, and there is usually little incentive for politicians to reform in expansionary phases. However, the unemployment rate surged from $8 \%$ in 2007 Q 3 to already $17.4 \%$ in 2009 Q1, and yet it took until June 2010 for the next labor reform to happen. We now discuss why and how that reform and other measures that followed were undertaken. We start by reviewing the literature on the determinants of structural reforms and then discuss the specificities of the Spanish setting.

\subsection{Which factors trigger reforms?}

The literature on the timing of structural reforms has not yet provided a set of strong and widely accepted factors that are conducive to reform. We therefore provide a very brief review of a few representative results found in the literature.

Saint-Paul (2002) finds that the relationship between the business cycle and the timing of labor market reforms is not robust, except for marginal ones -i.e. those that do not strongly alter labor market institutions- and for two-tier reforms that only affect the flexible tier of the market, e.g. fixed-term contracts. An important finding is the exposure effect, namely that reforms happen when unemployment is rising, not just when it is high, so that insider workers are in danger of losing their jobs. Another interesting result is that across-the-board reforms are mostly undertaken by right-wing governments.

Duval and Elmeskov (2005), referring to structural reforms in general, find that economic crises and high unemployment do induce reforms. Somewhat surprisingly, they also find that the absence of monetary policy autonomy is associated with lower structural reform activity. ${ }^{6}$ They also conclude that a sound fiscal balance may help undertaking reforms and that reforming one area (say the product market) induces reform in other areas.

Lastly, Høj et al.'s (2006) results indicate that big economic crises are associated with higher overall reforms, but in the cases of job protection and benefit systems reforms happen mostly in strong upswings. They also find that governments that have been in office for some time are more able to reform and that, on average, left-of-center governments reform less. These authors also confirm the last two conclusions of Duval and Elmeskov (2005).

\subsection{Serial reformers?}

As discussed earlier, labor market reforms are hardly unknown in Spain. Thus, one could argue that, on top of the standard resistance to reform, Spain also suffers from reform fatigue. It is therefore instructive to compare the Spanish experience regarding employment protection with that of the three other major continental European economies -France, Germany, and Italy- to check if there are objective grounds for fatigue, i.e. to ask whether Spain has experienced an unusual frequency and/or intensity of labor market reforms. In Table 2 we show (in percentages) the fraction of years in which there 
Table 2 Employment protection legislation reforms of specific aspects (\% of total)

\begin{tabular}{lcccccc}
\hline & Period & $\begin{array}{c}\text { Years with } \\
\text { reform }\end{array}$ & $\begin{array}{c}\text { Flexibility } \\
\text { increasing }\end{array}$ & Structural & Complete & Discrete \\
\hline France & $1982-2007$ & 56 & 68 & 32 & 18 & 44 \\
Germany & $1985-2007$ & 50 & 72 & 39 & 22 & 36 \\
Italy & $1982-2007$ & 56 & 68 & 32 & 18 & 44 \\
Average: & & 54 & 69 & 35 & 19 & 41 \\
Spain & $1980-2007$ & 48 & 61 & 24 & 21 & 29 \\
Versus & & \multicolumn{7}{c}{ Decreasing } & Marginal & Two-tier & Incremental \\
Source: Own computations with Fondazione Rodolfo DeBenedetti-IZA Social Reforms Database (www.frdb.org), see Boeri (2011).
\end{tabular}

have been measures reforming EPL, as well as the fractions of measures which have been flexibility-increasing (as opposed to decreasing), structural (v. marginal), complete (v. two-tier) and discrete (v. incremental), all of them as labeled in the Fondazione Rodolfo DeBenedetti-IZA Social Reforms Database (www.frdb.org). ${ }^{7}$

Are the reform frequency and intensity comparatively high? Table 2 shows that the frequency is similar, and if anything, reforms have been less flexibility-increasing, less structural, and more incremental, though slightly more complete than in the other countries. Also, note that close to $40 \%$ of reforms have been flexibility-reducing, a higher share than elsewhere, indicating a high degree of regulatory uncertainty for both employers and workers. Given this evidence, and against a backdrop of worldwide globalization and accelerated technical progress, it is hard to argue that the Spanish citizenry have reasons to be more reform-fatigued than in the other major European economies. But it may still be that perceived insecurity is very high in Spain. Let us look at the data.

\subsection{Perceptions of insecurity}

Do Spanish workers feel very insecure in their jobs? At first blush, not really. In 2005 Spain ranked sixth in the share of respondents who strongly agreed with the statement "My job is secure", only below Denmark, Ireland, Romania, Slovenia, and the US, among 19 nations. ${ }^{8}$ Though there surely are business cycle effects, note the lack of correlation with standard indices of employment rigidity: three of those high-security perception countries feature very lax EPL, whereas the other three have very stringent EPL. Indeed, Dolado et al. (2010) argue that there is U-shaped relationship: perception of insecurity is high at the two extremes and lower in the middle.

Moreover, as these authors remark, there is a fallacy of composition. There are large differences in opinions about job security among different population groups. Temporary contracts are more prevalent the younger the worker and this clearly shows up in perceptions. Figure 6 breaks down perceptions of job insecurity by age group. Spain shows a steep upward pattern which is quite uncommon in the other economies included in the survey. The average for the other 18 countries shows hardly any slope from 16-24 to 4554 years old. Indeed, the degree of insecurity perceived by Spanish 16-24 year olds is one standard deviation above that average and the insecurity felt by $45-54$ year olds is 1.7 standard deviations below the average.

These differential perceptions have been validated by subsequent developments. From 2007:Q4 to 2010:Q4 employment of the 16-24 year olds fell by 41.9\% but that of workers aged $45-54$ years old grew by $2.4 \%$. This is a much larger difference than in the Eurozone, where the respective figures were $-13.3 \%$ and $4.6 \%$, i.e. an 18 percentage-point difference 


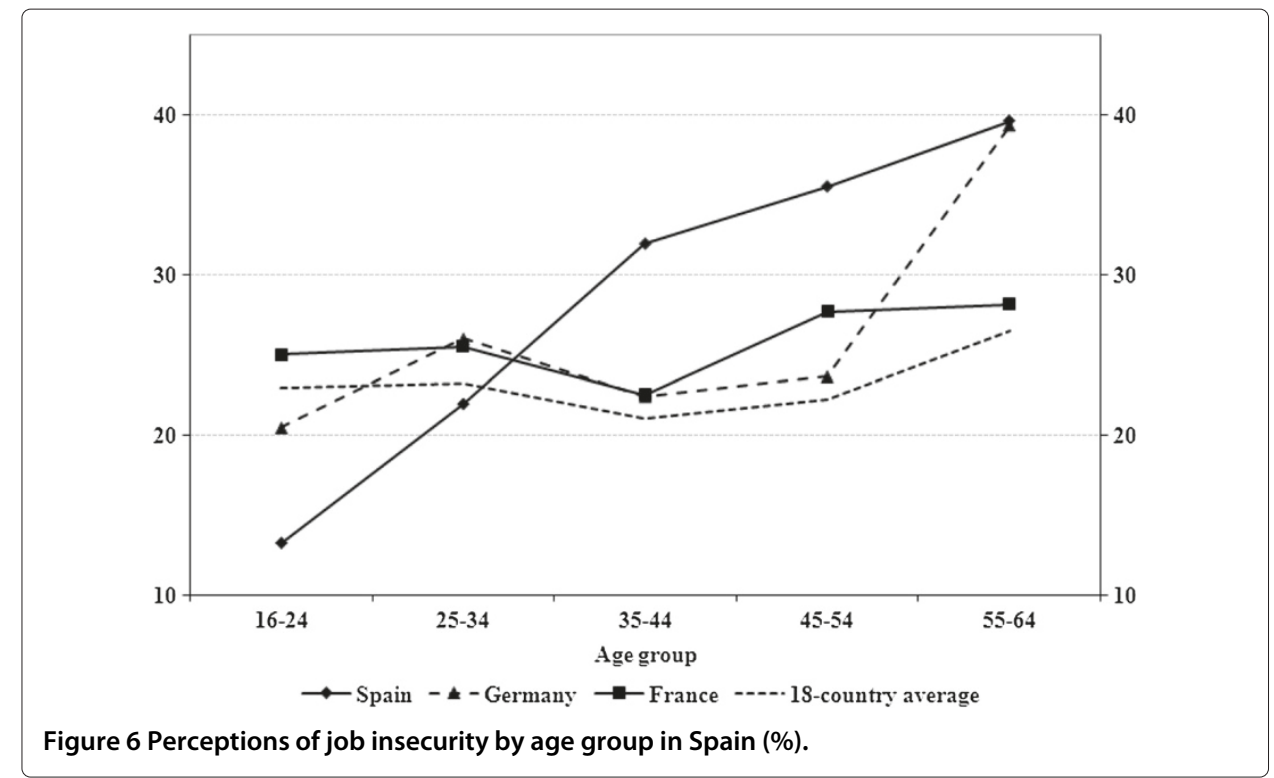

versus the $44.3 \mathrm{pp}$. for Spain. Both perceptions and realizations confirm the deep divide between insiders and outsiders. However, since political economy is driven by votes, do these perceptions translate into a differential degree of support for labor market reform?

\subsection{Political support for reforms}

What are voter attitudes regarding labor market reform? Table 3 presents the percentage share of respondents in Spain and in the EU15 countries, according to different characteristics, who agree with the following statement: "Work contracts should become more flexible to encourage job creation", from the May-June 2009 Eurobarometer (source: Dolado et al., 2010).

\section{Table 3 Attitudes towards labor market reform ( $\%$ of respondents)}

\begin{tabular}{lcc}
\hline & Spain & EU15 \\
\hline Population 16 years old and over & 61.2 & 71.2 \\
- 16-24 years old & 64.9 & 71.2 \\
- 45-54 years old & 60.1 & 69.4 \\
- 55-64 years old & 58.8 & 68.6 \\
Employed (16-64 years old) & & \\
- Expect to keep their jobs in near future & 57.2 & 69.4 \\
- Do not expect to keep their jobs in near future & 61.7 & 70.0 \\
Non-employed (16-64 years old) & & 73.5 \\
- Lost their jobs during the crisis & 70.3 & 70.5 \\
- Did not lose their jobs during the crisis & 60.0 & \\
Current labor status (16-64 years old) & & 77.4 \\
- Self employed/Entrepreneurs & 67.2 & 68.5 \\
- Managers & 62.2 & 73.6 \\
- Salaried professionals & 65.3 & 67.3 \\
- Other skilled employees & 51.0 & 71.2 \\
- Low-skill employees & 69.3 & 72.6 \\
- Unemployed & 69.6 & \\
\hline
\end{tabular}


The survey data reveal that there is indeed more resistance to labor market reform among Spanish nationals than among EU15 citizens, though all the shares are still above $50 \%$. There is again a much larger gap between the 16-24 year olds and the $45-54$ year olds in Spain (4.8 pp.) than in the EU-15 (0.6 pp.). It is also noticeable that the social groups that are more favorable to labor reform are low-skill employees and the unemployed, which are not the most politically influential ones.

Let us now look at the support that could be expected from the insiders. As already pointed out, according to Saint-Paul (2002), labor reform is more likely to happen the higher is the exposure of insiders to the risk of job loss. Following the arguments given in Section 3, we shall consider the insiders as being those with permanent jobs, whereas temporary employees and the unemployed are classified as outsiders. Moreover, among employees with permanent contracts, there are some with the old "ordinary" contract (entitled to 45 days' wages p.y.o.s., with a maximum of 42 months' wages in case of unfair dismissal) and entrants hired under the new, employment-promotion permanent contract (entitled to 33 days' wages p.y.o.s., with a maximum of 24 months' wages in such case). Since, as indicated above, the turnover rate for the latter is much higher than for the former, it is therefore unclear whether their interests regarding labor market reform are really close to those of workers on ordinary contracts.

Taking these caveats into account, Dolado et al. (2002) argue that the likelihood of labor market reform should be higher when outsiders represent the majority of workers. They construct two indexes of the weight of outsiders in the Spanish labor force, depending on whether or not workers under employment-promotion permanent contracts are considered as insiders. Figure 7 plots these two indexes for the period 1987Q2-2011Q2. The lesson to be drawn is that the 1994 and 1997 reforms took place at a time when outsiders outnumbered insiders (i.e., their incidence was above 50\%). Then, as a result of these reforms and of the subsequent boom of 1997-2007, the fall in unemployment and the rise in the use of permanent contracts for new hires implied a large reduction of the fraction of outsiders quite below $50 \%$, which is consistent with the lack of major reforms during

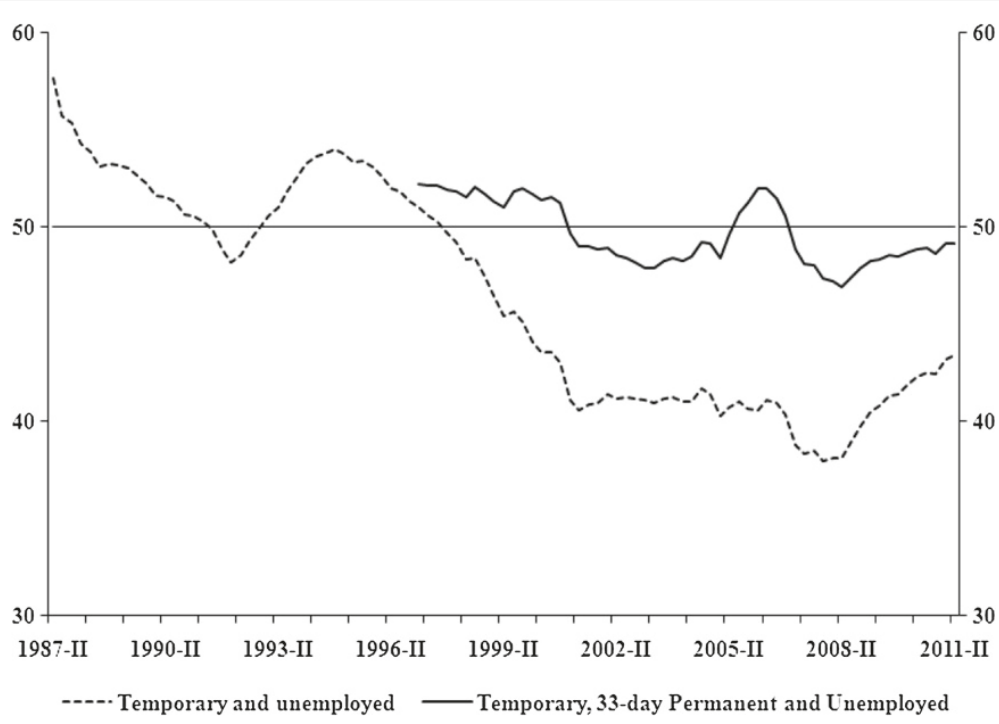

Figure 7 Outsiders as a share of employees and the unemployed in Spain (\%). 
this period. Note that, even after the adverse employment effect of the Great Recession, the fraction of temporary and unemployed workers remains around $42 \%$, since most dismissed workers previously held temporary contracts, so that there has been a sizeable change in the composition of outsiders but not in its size. If we adopt the wider measure of outsiders that includes workers under employment-promotion contracts, the fraction of outsiders comes closer to $50 \%$, though in strictly speaking it is still below the majority. We therefore do not get a clear signal from this indicator on why another reform took place in 2010.

Alternatively, it is interesting to look at how employment losses have been distributed among workers according to contract type. As can be observed in Figure 8, temporary jobs have fallen precipitously since the early phases of the crisis, while permanent jobs kept on rising, suffering the first drop only in 2009Q3. Taking 2007Q3 as the start of the recession, the stock of employees on temporary contracts has fallen by around $30 \%$, whereas permanent employment has only fallen below the 2007Q3 value in 2011Q1. These figures suggest that insiders have not been overly exposed yet, though their jobs are starting to be threatened. Quite tellingly, Dolado et al. (2010) estimate that $99 \%$ of job losses from 2007Q3 and 2009Q3 came from workers not affiliated with labor unions.

\section{Crisis-induced reforms}

\subsection{Labor reforms during the Great Recession}

The extraordinary rise in unemployment in Spain since 2007 was insufficient to trigger labor market reform. Before and during the Great Recession, the Spanish Socialist government did not think that such a reform was necessary and stated that, in case one were to be undertaken, it would come from an agreement between the social partners, i.e. the two main labor unions and the employers' association. Talks were held between those partners for more than two years without any agreement.

At that stage of the crisis (around November 2009) the standard measure of the risk premium on public debt, the differential between the yield of the Spanish 10-year bond

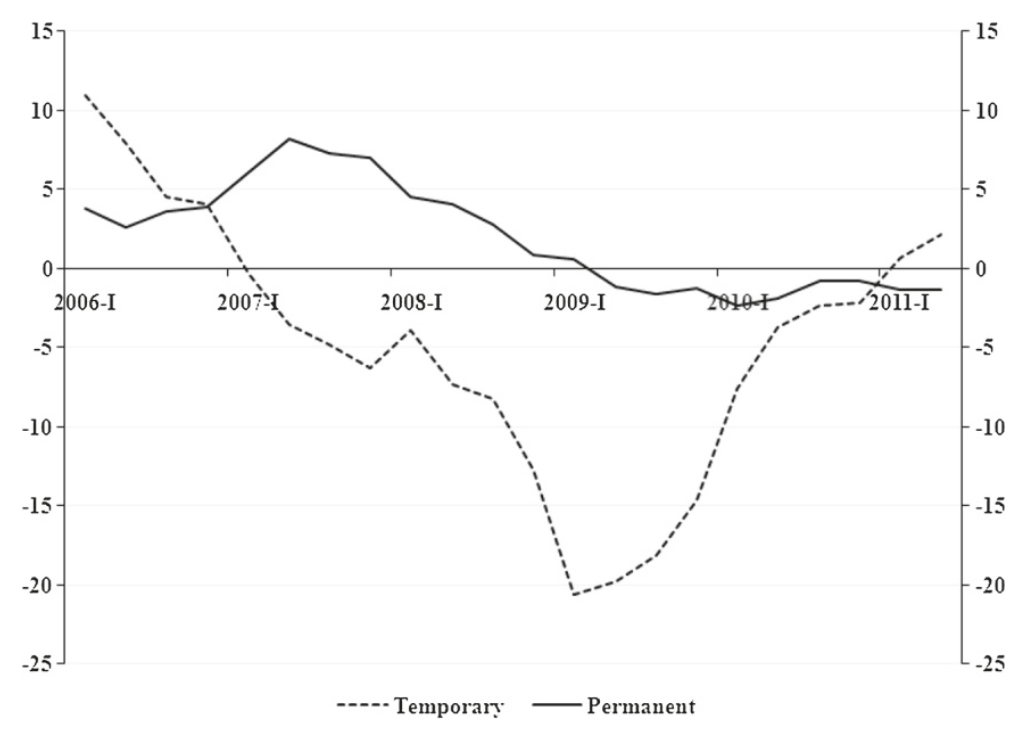

Figure 8 Permanent and temporary employment growth in Spain (annual change, \%). 
and the equivalent German Bund stood at 55 basis points. December 2009 brought the start of the crisis that eventually led to the first Greek bailout, with the Spanish differential raising to around 70 basis points in March. Then risk premia escalated in most peripheral Euro Area member countries, reaching a sharp peak of 165 basis points on 7 May. At a momentous weekend summit on 9 May 2010, the European Union agreed to create the European Financial Stability Facility (EFSF), a special purpose vehicle financed by members of the Eurozone to combat the European sovereign debt crisis. Subsequently, on 12 May the Prime Minister announced sizeable cuts in the central Government budget, including a 5\% cut in public sector pay in 2010 and the freezing of public pensions in 2011. After a brief fall, the risk premium sharply rose from 95 basis points, when the May budget cuts were announced, to 217 basis points on 16 June 2010. This date marks both the passing of a labor reform decree by the Government and a peak in the risk premium, which fell thereafter and did not surpass that date's value until November 2010, when the Irish debt crisis erupted.

Hence, forced by the financial markets' external threat, the Government abruptly changed its views on the need for a labor market reform, and put some more pressure on social partners to reach an agreement. In early February 2010 the Government had issued a set of guidelines for EPL reform to be discussed by the social partners and to be used as the foundation for the reform. Nevertheless, as talks stalled, it went ahead with a reform that followed the same strategy of the previous ones, namely, mildly reducing dismissal costs and relaxing dismissal restrictions under the employment-promotion permanent contracts while doing the opposite for temporary contracts.

As to changes in the regulation of collective bargaining, the reform process and the results were similarly meager. After the EPL reform, trade unions called for a general strike on 29 September 2010, which was largely a failure. However, one month later a new Minister of Employment was appointed-a card-carrying member of one of the two main labor unions, who had attended the general strike demonstrations-, with the main goal of restoring the social dialogue. Then, some guidelines for the reform of collective bargaining were issued and the Government waited for an agreement between the social partners on that issue. The agreement never came and the Government proceeded again with another mild reform in June 2011 (see below).

\subsection{Contents of the reforms}

At first glance, the 2010-2011 reform was quite comprehensive, affecting the following four areas: severance pay, hours reduction, active labor market policies, and collective bargaining. A summary of the key measures follows.

Firstly, in the area of individual dismissals, there were several noticeable changes: (1) In dismissals for economic reasons, current and expected losses or a persistent reduction in revenues were included as causes for fair dismissal. Other, broadly-understood, economic reasons -technological, organizational, and productive- were explicitly defined for the first time. Advance notice was reduced from 30 to 15 days. (2) A new employmentpromotion permanent contract was introduced, enlarging the group of eligible workers and extending to this contract the express dismissal procedure, i.e. maximum severance pay of 33 days' wages p.y.o.s. to avoid going to court, with neither advance notice nor 
interim wages (previously firms paid 45 days through disciplinary dismissals). (3) For temporary contracts, a schedule of progressive increases in severance pay, from 8 days of wages p.y.o.s. to 12 days (to be reached in 2015), was established. (4) The duration of a sequence of temporary contracts of a given worker in the same firm was capped at 3 years for hitherto unlimited specific-work contracts. ${ }^{9}$

Secondly, in line with the successful experience of the Kurzarbeit programme in Germany, hours reductions were facilitated, by reducing social security contributions on firms and extending workers' entitlements to unemployment benefits. Thirdly, in the realm of active labor market policies, the groups of workers eligible for job creation subsidies were restricted and private placement agencies were authorized for the first time. Lastly, regarding collective bargaining, firms in distress were allowed to opt out of the industry collective-bargain wage level by reaching an agreement with its workers, though the corresponding level had to be re-attained in no more than 3 years. The new reform of collective bargaining of June 2011 established that firm-level agreements prevail over the corresponding industry-wide agreements, but only if the latter does not say otherwise. Also, over the subsequent year, agreements that expire and are not renewed will be subject to compulsory arbitration (until industry-wide agreements decide on whether this should be the rule).

\subsection{What kind of reforms?}

As mentioned earlier, in our view, labor reform was triggered by external pressure coming from international financial markets. We are not the first to argue about this channel for reform. Bertola (2010b) indicates that countries suffering high public debt are more likely to undertake labor reforms and finds some empirical evidence weakly supporting this claim. While causation is clear for countries that had to be bailed out, i.e. Greece and Portugal (whose respective Memorandum of Understanding with the ECB-EU-IMF troika include very specific labor market reform measures), it is not so apparent for non-bailed out countries.

The source of the reform does matter. Since neither the Government nor the social partners were interested in the reform, the kind of reform that was undertaken did not significantly reduce the fundamental insider-outsider divide in the Spanish labor market. Firstly, the reform included measures that labor unions disliked, but it was made more palatable by reducing its scope. Indeed, the two most important institutions generating high and volatile unemployment, but which also benefit both employers and labor unions, were modified in a sufficiently marginal way that their core was left in place. These are the dual EPL (see Saint-Paul, 2000) and the regulation of collective bargaining. Secondly, some of the measures introduced were meant to benefit insiders, such as the subsidies for reduced hours (as opposed to dismissals). Lastly, some of the measures have been subsequently undone, like the backtracking regarding limits on chaining of temporary contracts (see the preceding footnote) and raising the chances that workers will challenge individual dismissals in court. ${ }^{10}$

It is still too early to assess the effect of these reforms, though the prospects are far from good, as unemployment exceeded 5 million at the end of 2011. In view of these adverse circumstances, in the next section we propose a set of measures of labor market reform that we believe should be undertaken to help reverse the insider-outsider divide, so as to permanently reduce the Spanish unemployment rate. 


\section{Towards eliminating the insider-outsider divide}

As argued in the previous sections, despite a long sequence of unsuccessful reforms at the margin, the very high and persistent segmentation prevailing in the Spanish labor market since the late 1980s is the key factor behind its huge employment and unemployment volatility. Temporary contracts do not only bear the brunt of the adjustment during recessions but they also negatively affect the career developments and productivity of temporary workers (typically young, female, and low-skill), who face a low probability of advancing towards a long-term employment relationship.

Given these negative effects, clearly illustrated by the evolution of the Spanish labor market since the onset of the Great Recession, there is a growing consensus among academics that more reforms at the margin, like the one approved in 2010-2011, are bound to remain ineffective. On the one hand, timid attempts to reduce severance pay for some permanent contracts that are not available for all workers still leave a too high firing cost gap, as reflected by the scarce use of the new employment-promotion contracts. On the other, moving back to the labor market of a few decades ago by severely penalizing the use of temporary contracts while keeping the current levels of EPL for permanent contracts is not a viable option either. This would just prevent job creation in the subsequent recovery and make the labor market uniformly much more rigid. Thus, a more radical approach is needed to reduce the firing cost gap between permanent and temporary workers, thus paving the way to a quality job-rich recovery and, foremost, to a better balance between flexibility and social protection. More specifically, new regulations need to be introduced so as to provide a viable alternative for firms to the overuse of temporary contracts, with the key goal of eliminating the detrimental effects of the excessive churning of temporary workers on job stability, training, and future career prospects.

\subsection{A single open-ended contract}

In parallel with similar policy initiatives in Europe, namely those of Blanchard and Tirole (2003) and Cahuc and Kramarz (2004) for France, Boeri and Garibaldi (2008) and Ichino et al. (cr33) for Italy, and Bentolila et al. (2008) for Spain, a manifesto signed by 100 academic economists, see Andrés et al. (2009), was launched in Spain, defending the suppression of the firing cost gap once and for all. To achieve this goal, a key policy advice in this proposal is the introduction of a single open-ended contract (SOEC hereafter) for new hires, at the same time that temporary contracts were abolished -with the exception of replacement contracts for maternity or sickness/disability leaves. The key feature of SOEC is that it has no ex-ante time limit (unlike fixed-term contracts) and that severance payments smoothly increase with seniority, instead of having the same indemnity per year of service applying from the start (unlike current open-ended contracts). In this fashion, and in contrast with the current regulation of permanent contracts, the SOEC provides a sufficiently long entry phase and a smooth rise in protection as job tenure increases. The rationale for the gradually increasing severance pay is that the longer a worker stays in a given firm, the larger are her/his loss of specific human capital and the psychological costs suffered in case of dismissal (Blanchard and Tirole 2003).

A substantial advantage of SOEC over the current dual EPL regulation is that it drastically reduces the marginal cost, in term of expected severance pay, faced by employers when deciding whether to upgrade expiring temporary contracts into permanent ones. The large reduction in the marginal cost of contract extensions (of 2 or 3 days' wages 
p.y.o.s. until a reasonable steady value is reached after 10 years, say) would prevent massive redundancies and the huge turnover of temporary workers, which have taken place in the last two recessions. The reason is that the entry phase with low firing costs would encourage job creation and reduce inefficient churning of temporary workers, while the very gradual increase in severance pay will foster longer job durations without necessarily harming employers, as uncertainty about the quality of job matches would entail a much lower cost. As discussed below, even if the expected compensation p.y.o.s. turned out to be to be lower under the SOEC than under current EPL, it is quite plausible that the longer job tenure induced by the fall in the firing cost gap would increase the total expected compensation received by dismissed workers, echoing a Laffer curve effect.

To illustrate these ideas, let us consider a Spanish worker with a prototypical job tenure of 10 years, where the first 2 years are under a temporary contract and the remaining 8 years under a permanent one. Figure 9 depicts the marginal severance pay in case of dismissal up to 10 years working at the same firm under current EPL regulations with the rights that would be provided by a conceivable specification of a SOEC. The latter (labeled as SOEC 12-36 hereafter) starts with 12 days' wages p.y.o.s. and grows by 2 days per year to a maximum of 36 days' wages, so that compensation is incremental, with a maximum of 24 months' wages. Under current regulations, since firing costs for a temporary contract entails 8 days' wages p.y.o.s., while those of a permanent contract typically amount to 45 days' wages p.y.o.s. (after Law 45/2002), the expected total dismissal cost to the firm would be 376 days' wages $(=2 \times 8+8 \times 45)$. The alternative option for the firm would be to use five temporary contracts in sequence (offered to different workers) instead of converting the temporary contract into a permanent one after the first two years. In this case, the firm would pay 80 days' wages $(=8 \times 10)$. Thus, the gap in expected firing costs for the firm of contract conversion amounts to 296 days' wages $(=376-80)$, i.e. slightly more than $80 \%$ of a yearly wage. In contrast, under SOEC $12-36$, the expected total severance pay would be 210 days' wages $(=12+14+\ldots+30)$, so that the firing cost gap would fall to only

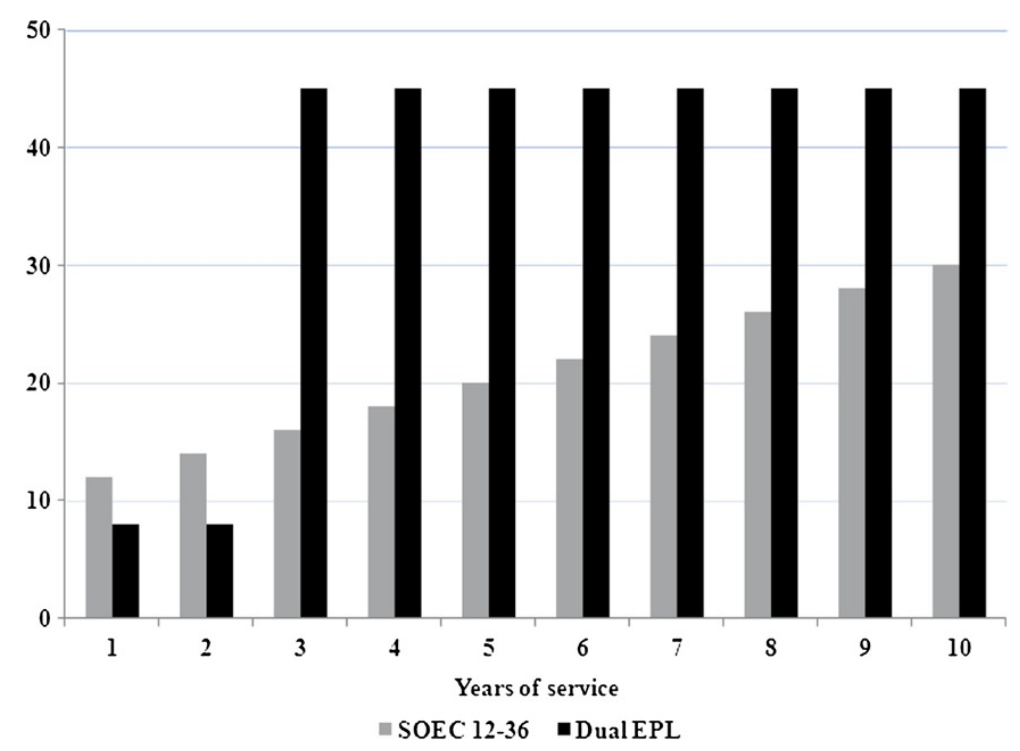

Figure 9 Marginal severance pay in dual EPL and in SOEC 12-36. 
130 days' wages $(=210-80)$. This amounts to a reduction of $56 \%$ vis-à-vis the current regulation, which is bound to increase job creation and job duration significantly, as well as to reduce job destruction. The combined effect of these favorable outcomes should lead to a noticeable reduction in unemployment.

\subsection{Evaluating the effects of introducing a single open-ended contract in Spain}

There have been a few papers quantifying the above-mentioned implications of the SOEC proposal that we summarize in what follows. The first strand of this literature relies on calibrating search and matching models of the labor market, along the lines of Mortensen and Pissarides' (1994) classical model with endogenous job creation and job destruction, but extended to allow for the existence of temporary and permanent contracts entailing very different dismissal costs. ${ }^{11}$

Bentolila et al. (2012) estimate the proportion of the much larger increase in Spanish than in French unemployment during the Great Recession that is due to the larger firing cost gap in Spain than in France. They focus on a comparison of these two neighboring countries not only because they share quite similar labor market institutions, including the use of temporary contracts, but also because their unemployment rates just before the crisis were almost identical (around 8\% in 2007). Yet, while the unemployment rate in France has only increased by about 2 percentage points (pp.) by the end of 2009, it shot up to $19 \%$ in Spain over that period (23\% nowadays). As discussed earlier, the fact that both countries exhibit similar overall indexes of strictness in EPL in the well-known OECD (2004) rankings is due to how these indexes are constructed, i.e. on the basis of legal regulations and not on their implementation. Indeed, when discussing the enforcement of the legislation, they argue that de facto EPL of temporary jobs is much weaker in Spain than in France, whereas the opposite holds for regular permanent jobs.

Further, to estimate the relevant EPL gap in each country, they adopt the conservative view that what affects employment is not legal severance pay per se, which is a transfer from the firm to the worker and may therefore be compensated for in the wage bargain (Lazear 1990). Rather, what matter are other costs generated by third agents, like labor courts and labor authorities, which cannot be appropriated by firms and workers and therefore cannot be neutralized through wage bargaining. These are the so-called red tape costs, which they estimate to be 50\% higher in Spain than in France. In view of this large gap, the research question they address is by how much would Spanish unemployment have been reduced during the Great Recession, relative to its actual rise, had Spain adopted the lower French EPL gap before the start of the slump, instead of keeping its own EPL regulations.

Their strategy is to calibrate the above-mentioned analytical model to match the main stylized facts (average flows and stocks) in the French and Spanish labor markets before the recession (2005-2007). Then, keeping invariant the calibrated parameters in this first stage, they proceed to match the new stylized facts during the recession (2008-2009), by allowing only for an adverse aggregate productivity shock and, in Spain, a negative reallocation shock. These two shocks are meant to capture, respectively, the severity of the recession and the increase in mismatch induced by the collapse of the construction industry as a result of the credit crunch. Once the model is well calibrated in both the good and bad state, they run a counterfactual simulation during the recession (imposing 
the same adverse shocks estimated before) where the Spanish EPL gap is replaced by the much lower French gap.

Their main finding is that, with the French EPL gap and taking into account its indirect, mismatch-reducing effect, Spanish unemployment would have increased by $45 \%$ less than what it actually did (i.e. from $8 \%$ to $14 \%$, rather than to $19 \%$ ). Further, a similar counterfactual simulation during the preceding expansionary period yields that unemployment would have been 2 pp. lower during 2005-2007, i.e. 6\% rather than 8\%. Overall, these results indicate that, due to the inefficient turnover they induce, facilitating the widespread use of temporary contracts is likely to raise average unemployment over the business cycle in labor markets with already rather stringent permanent job security provisions.

A related paper is Costain et al. (2010), which addresses the issue of high unemployment volatility in strongly dual labor markets. Rather than focusing a single event, like Bentolila et al. (2012) do with the Great Recession, these authors study labor market dynamics over the business cycle following a sequence of auto-correlated, match-specific productivity shocks. After calibrating a similar search and matching model with permanent and temporary contracts to the Spanish labor market during 2001-2008, they compare the volatility of unemployment under two alternative scenarios regarding firing costs: under the current, dual EPL and under a unified labor market with a single contract where firing costs are equal to the average severance pay in the dual labor market (but where the firing cost does not increase with job tenure). Their main finding is that the unemployment rate in the dual labor market fluctuates $21 \%$ more than in the unified case.

The intuition behind this result is that while new permanent jobs must have relatively high productivity (to compensate firms for future high severance pay), in temporary jobs with low or no dismissal costs firms are instead willing to hire workers with lower productivity. Hence, the latter jobs become very fragile as soon as there is an adverse shock. In other words, the stock of fragile jobs accumulates rapidly in expansions and becomes immediately destroyed when a recession hits. According to these results, introducing a single contract would unambiguously reduce volatility but, by hampering the hiring of low productivity workers, it would also increase unemployment by $2 \mathrm{pp}$. (from $10 \%$ to $12 \%$ during the calibration period). Their simulations show that, in order to avoid this rise in unemployment, average firing costs would have to fall by $60 \%$ in their sample period. Interestingly, as discussed above, this reduction in average firing costs turns out to be quite similar to the one implied by the introduction of SOEC 12-36.

The quantitative evaluation of the effects of the SOEC 12-36 proposal is directly addressed in this type of search and matching models by García Pérez and Osuna (2011), which analyzes the transition between the existing dual EPL and this specific design of SOEC. They focus not only on simulating the effects of this change of regulations on unemployment but also on how this change would have affected workers' job tenures over the period 1998-2009, which comprises both a long expansionary phase and the subsequent recession. Their strategy is similar to the one used in the previous two papers: calibrate the parameters of the model to match the main stylized facts of the Spanish labor market over the chosen period and then run counterfactual simulations under SOEC 12-36. Their results show not only that the unemployment rate would be $3 \mathrm{pp}$. lower under the single contract but, more importantly, that the number of workers with job tenure below one year would be almost $25 \%$ lower than under current EPL, while the 
number of workers with tenure longer than three years would become $15 \%$ higher under SOEC 12-36. The intuition for these results in again similar to the one discussed above: under the latter contract, the probability of being fired in contracts with tenure below four years is almost halved, because firms are much less reluctant than before to destroy jobs since they are costlier (12 days' wages p.y.o.s. v. 8 days' wages p.y.o.s.) and because the jump in severance pay (from 8 to 45 days' wages) has been replaced by a much smoother gap ( 2 days for each year the contract is extended, up to an upper bound of 36 days' wages).

A second strand of this literature uses a different simulation approach to evaluate other relevant consequences of the introduction of SOEC 12-36, as well as those of other alternatives, like a combination of a single contract and a capitalization fund for dismissals, in line with the so-called Austrian model. The idea behind this fund is that, rather than paying a statutory severance pay to the worker at the termination of a labor relationship, firms deposit every month a given (small) amount of days of salary for all their workforce into an individual fund for every worker, to be used in case of dismissal, relocation, engagement in educational activities or eventually upon retirement. The idea is that a worker's fund does not disappear upon changing jobs -as happens with current EPL- and it therefore fosters worker mobility. In particular Conde Ruiz et al. (2011) focus on the effects of introducing two alternative single contract schemes on the expected average severance paid by firms and received by different types of workers after 10 years, relative to what they would respectively pay and receive under the status quo.

The first scheme is SOEC 12-36, while the second scheme is a combination of a SOEC entailing lower firing costs, increasing from 12 to 24 days' wages in 7 years, with a capitalization fund of three days' wages per year (SOEC 12-24 +F3), both with a maximum entitlement of two years' wages. To simulate these effects, they use information at the individual level on wages, hiring, firing, and contract conversion rates for unemployed, temporary, and permanent workers over their working life, using a $4 \%$ random sample of the Spanish social security registers for 2009. ${ }^{12}$ The paths arising from these rates are then projected over the next decade to evaluate the effect of alternative EPL regulations. Specifically, drawing from the endogenously determined job creation, job destruction, and contract conversion rates obtained by Costain et al. (2010) and García Pérez and Osuna (2011) in their counterfactual simulations of general equilibrium search and matching models, it is assumed that the firing rate under SOEC will be on average $60 \%$ lower than those observed for temporary workers with less than 4 years of job tenure and 35\% higher for permanent workers with job tenure above 4 years. The latter is assumed to capture the potential adverse effect of a SOEC reform exclusively applied to new workers (i.e. not retroactively) on workers with old permanent contracts, through a replacement of these workers -entitled to high severance pay- by new contracts under the cheaper SOEC. The main finding of these (partial equilibrium) models is that SOEC $12-24+$ F3 provides on average $15 \%$ higher severance pay for workers than under the status quo and $13 \%$ more than under a pure SOEC 12-36, while the average firing cost to firms over the 10 year period is approximately the same. Thus, the mixed proposal of a SOEC and a capitalization fund seems to be a more beneficial alternative in order to reduce the degree of segmentation in the Spanish labor market, through its effects on job duration, job mobility, and greater incentives to invest in human capital. 


\subsection{Other policy proposals}

A SOEC would not be the cure-all for the Spanish labor market. The extremely high unemployment rates that have been reached are the result of a systemic failure, involving also the structure of collective bargaining, unemployment benefits, and active labor market policies. In this section we briefly review appropriate lines of reform in those areas.

Among the many government policies that can affect wage developments (public sector wages, minimum wages, labor taxation, etc.), the regulation of collective bargaining is probably the one having the strongest bearing on labor cost developments. The coverage of collective bargains, the level at which wages are set, the extension of bargained wages to workers and firms outside the scope of an agreement, the existence of coordination mechanisms or the application of wage indexation clauses are clearly determined by the social partners. But these features are very strongly influenced by both labor legislation and the intervention of governments in the social dialogue.

As indicated in Section 3, empirical studies reveal little real wage adjustment to unemployment or to productivity changes. This yields a significant increases in equilibrium unemployment, as has been argued by Jimeno and Thomas (2011), using a calibrated version of a Mortensen-Pissarides (1994) model with heterogenous firms. They also show that allowing for opting-out of industry-wide collective bargaining agreements would reduce unemployment to the same level achieved under efficient firm-level bargaining without major changes in either average wages or wage inequality. Real wage rigidity has two important consequences in the current situation. First, regarding the employment impact of the crisis, the lack of wage adjustment increases job destruction. Secondly, looking ahead, the requirements for restoring output and employment growth, namely nominal adjustment, the closing of the competitiveness gap, and the reallocation of resources from the non-tradable to the tradable sector, are all harder to implement.

Hence, regulatory reforms should affect collective bargaining practices in order to bring wages more in line with productivity changes. This requires giving more scope to firm-level bargaining, even for those firms within the coverage of industry-wide agreements, and limiting the use of wage indexation rules. As indicated in Section 5, the labor reforms of June 2010 and June 2011 eased the opt-out of industry agreements and established firm-level agreements as the default ones. However, by giving labor unions and the employers' association an effective veto over this change, it is not clear whether these changes will deliver a significant increase in the degree of decentralization.

We strongly believe that the SOEC and making opting-out of sectorial collective bargaining truly operational would eliminate the insider-outsider divide, and that this would bring very positive consequences in terms of job creation, giving scope to most-needed productivity gains and, last but not least, reducing earnings inequality among Spanish workers. The two fundamental measures that we advocate would surely need further refinements and being complemented by others geared towards reducing long-term unemployment, such as introducing some degree of experience-rating in unemployment benefits and improving the effectiveness of active labor market policies, by means of proper evaluation of their effects with financial consequences for the agencies in charge of the administration of those policies (see Andrés et al. 2009 for other proposals). 


\section{Conclusions}

The Spanish economy is currently in a dire situation. Reducing the indebtedness of the private and public sectors is urgent, as external financial conditions are very unfavorable. As monetary policy, within the Monetary Union, is out of domestic control, and fiscal policy is constrained by the current financial conditions, supply policies should take the most prominent role in the policy agenda. It is urgent to increase productivity growth, while at the same time creating jobs, so as to make the reduction of indebtedness less painful in terms of consumption, to domestically provide new funds for investment, and to restore the competitiveness lost since access to the EMU.

Labor market reforms are key to restart productivity growth. We do not believe that they are also sufficient, as there are many other areas in which structural reforms should be contemplated. Two important points that policy-makers need to consider are:

1. Labor market reforms and product market reforms ease the needed for fiscal consolidation process (see Gavilán et al., 2011). Reducing the insider-outsider divide and lowering barriers to competition in the product market would substantially increase job creation and productivity growth, so that fiscal revenues would be larger and public deficits and debt could be further reduced with a lower cost in terms of consumption.

2. Be aware of reform fatigue. As shown above, there have been far too many unsuccessful and contradictory labor market reforms. The new labor market reform will have to be implemented in the context of a very intense fiscal retrenchment, and with the public opinion being very critical of the poor management of the consequences of the crisis so far. In this context, it is crucial that the reform has clear goals, be communicated clearly to the public opinion, and being perceived as equitable.

The task is not easy, but its time has come.

\subsection{AdDENDUM}

After writing this paper, another labor market reform has been passed on 12 February 2012 by the newly elected Conservative Government. This new new reform has affected the following areas in comparison with the 2010-2011 reforms:

1. Severance pay. The causes for fair dismissal due to economic reasons are further clarified as including three quarters in a row of declining revenues/sales. Employment-promotion permanent contracts are eliminated and the severance pay for unfair dismissals is unified at 33 days, with a limit of 24 months' pay. The reimbursement of 8 days' wages in dismissals of permanent employees is now limited to fair dismissals in firms with less than 25 employees. The express dismissal procedure (see above) and the administrative approval of collective dismissals are both abolished. Lastly, a new permanent contract for entrepreneurs is created, with a one-year probation period (i.e. without severance pay) and substantial subsidies for companies.

2. Collective bargaining. Priority of firm-level agreements over industry-wide agreements is not anymore subject to overruling by the latter. Employers are now allowed, for competitiveness-related reasons, to unilaterally change working 
conditions, including wages, as long as these are above the industry collective-agreement level (workers may quit and get severance pay for objective dismissals or take the employer to court). The causes allowing firms in distress to opt out of the industry collective-bargain working conditions, including wage levels, are further clarified as having two quarters in a row of declining revenues/sales. Agreements expiring without mutually agreed renewal being feasible will be subject to compulsory arbitration, and now industry-wide agreements cannot rule it out. The maximum duration of working conditions after the expiration of the agreement is set at two years (previously being indefinite). Administrative approval of collective contract suspensions and work-time reductions is abolished.

The 2012 reform entails a substantial shift of bargaining power from workers to employers. Thus, by strengthening external adjustment, it has the potential of achieving the internal adjustments (wages, working time, mobility, etc.) that the Spanish economy badly needs to restore competitiveness. However, in a context of high indebtedness, substantial productivity growth is also required, not only as a complementary way to restore competitiveness, but also to sustain internal demand and, hence, restart employment growth. In this respect, the reform falls short of what is needed.

Further, in light of our previous considerations, one key issue which remains inappropriately addressed is dualism. The reform reduces the firing-cost gap between temporary and permanent contracts, which should encourage firms to use temporary contracts less. However, the incentive at the margin may prove insufficient, since the firing-cost gap (for a worker with job tenure of two years) between the 18 days of the temporary contract for a typical duration of these contracts and the 40 days (fair) or the 66 days (unfair), plus red-tape costs, is still large.

For this reason, the frictional unemployment created by the volatility of temporary contracts may not subside. Nor probably will their other negative effects, such as the lack of incentives to invest in human capital on the part of employers and workers, thereby negatively affecting productivity growth.

The second important shortcoming is the absence of changes in unemployment insurance and the very small changes in active labor market policies (ALMP). This reform relies almost exclusively on job creation subsidies in both the contract for entrepreneurs and in a new training contract, favouring youth, workers older than 45, women, and the long-term unemployed. Since job subsidies have traditionally entailed large deadweight losses and substitution effects in the past, increased expenditures on these items, against the backdrop of a planned reduction in the government budget deficit from 8.5 percent of GDP in 2011 to 3 percent in 2013, is likely to prove too costly.

In sum, the reform has advanced towards flexicurity but only in the flexi part (firing costs and internal flexibility). It also lacks significant productivity-enhancing measures. Though it represents an improvement, it is yet unclear how far it will reduce the Spanish structural unemployment rate and whether it will spur economic growth.

\section{Endnotes}

${ }^{1}$ This is the decomposition used by Burda and Hunt (2011), in their analysis of the German "Labor Maket Miracle" in the Great Recession, where employment losses have been much lower than expected from the output fall. 
${ }^{2}$ Austria, Belgium, Denmark, Finland, France, Germany, Ireland, Italy, Spain, Sweden, the United Kingdom and the United States.

${ }^{3}$ Source: Encuesta de Calidad de Vida en el Trabajo (Quality of Life at Work Survey). We are grateful to Florentino Felgueroso for providing us with these data.

4 “El Gobierno ha dado más de 1.000 millones a los sindicatos desde 2008”, Fernando Cancio, La Razón, 25 November 2011.

${ }^{5}$ For instance, Bentolila et al. (2010) found that a $1 \%$ upward deviation from the reference expected inflation rate, which was around $2 \%$ in the latter part of the boom, is associated with a $1.1 \%$ increase in nominal wages, whereas a $1 \%$ downward deviation is associated with a $0.3 \%$ fall in nominal wages. They also found that a 1 percentage-point increase in unemployment only reduces wages by $0.2 \%$ and that there is no significant association of wage growth with productivity growth.

${ }^{6}$ This is against the "There Is No Alternative" (TINA) hypothesis, see Bean (1998), and also against the weak empirical evidence for increased labor reform in EMU countries vis-à-vis non-EMU European countries in Bertola (2010a).

${ }^{7} \mathrm{~A}$ reform is considered structural if it is comprehensive, addressing the broader design of existing systems, rather than their minor features. Two-tier measures involve only a fraction of the potentially eligible population, regardless of size of the reform. Discrete reforms are those entailing a change in an institution which is larger than one-tenth of the cross-country deviation in the intensity of the regulation in the middle year covered by the dataset, i.e. 1995 (which goes from 0 to 6). See Boeri (2011).

${ }^{8}$ The other countries are Belgium, Bulgaria, the Czech Republic, Finland, France, Germany, Hungary, Latvia, Norway, Portugal, Sweden, Switzerland, and the United Kingdom. Source: Dolado et al. (2010) based on data from the International Social Survey Programme (www.issp.org).

${ }^{9}$ However, in September 2011 the maximum duration extension of all temporary contracts was extended to 4.5 years, until September 2013.

${ }^{10}$ In the October 2011 law regulating the social jurisdiction.

${ }^{11}$ This generalization is inspired by Blanchard and Landier (2002) and Cahuc and Postel-Vinay (2002), which are the first papers to allow for dual contracts in search and matching models.

${ }^{12}$ The database is the Continuous Sample of Working Lives (Muestra Continua de Vidas Laborales, Ministerio de Trabajo y Seguridad Social, 2002-2009).

Competing interests

The IZA Journal of European Labor Studies is committed to the IZA Guiding Principles of Research Integrity. The authors declare that they have observed these principles.

\section{Acknowledgements}

This is a revised version of a paper prepared for the Organisation for Economic Cooperation and Development and University of Maryland Conference on "Labour Activation in Times of High Unemployment" , Paris, 14-15 November 2011. We are very grateful to Edward Montgomery and an anonymous referee for helpful comments and to Florentino Felgueroso, J Ignacio García-Pérez, and Marcel Jansen for help and for letting us use their data.

Responsible editor: Sara de la Rica

\section{Author details}

${ }^{1}$ CEMFI, Calle Casado del Alisal, 5. 28014 Madrid, Spain. 2Universidad Carlos III, Calle Madrid 126. 28903 Getafe, Spain.

${ }^{3}$ Banco de España, Calle Alcalá 48. 28014 Madrid, Spain. 


\section{References}

Andrés J, et al. (2009) Propuesta para la reactivaci ón laboral en España, El País. 26 April: 20

Arpaia A, Curci N (2010) EU labour market behaviour during the Great Recession. European Economy - Economic Papers 405. European Commission, Luxembourg

Banco de España (December 2010) Encuesta Financiera de las Familias (EFF) 2008: Métodos, resultados y cambios desde 2005. Bolet ín Económico, Banco de España

Bean CR (1998) The interaction of aggregate-demand Policies and Labour Market Reform. Swedish Econ Pol Rev 5: 353-382

Bentolila S, Cahuc P, Dolado J, Le Barbanchon T (2012) Two-tier labor markets in the Great Recession: France versus Spain. Econ J 122: F155-F187

Bentolila S, Dolado J (1994) Labour flexibility and wages: Lessons from Spain. Econ Pol: A Eur Forum 18: 53-99

Bentolila S, Dolado J, Jimeno JF (2008) Two-tier employment protection reforms: The Spanish Experience. CESifo DICE Report 4/2008: 49-56

Bentolila S, Jimeno JF (2006) Spanish unemployment: The end of the wild ride? In: Werding (ed) Structural unemployment in Western Europe. Reasons and remedies. MIT Press, Cambridge. pp 317-343

Bentolila S, Jimeno JF, Izquierdo M (2010) Negociaci ón colectiva: La gran reforma pendiente. Pap Econ Española 124: 176-192

Bertola G (2010a) Labour markets in EMU: What has changed and what needs to change In: Buti M, Deroose S, Gaspar V, Nogueira Martins, J (eds) The euro: the first decade. Cambridge University Press, Cambridge. pp 715-758

Bertola, G (2010b) Fiscal policy and labor markets at times of public debt. Nordic Econ Pol Rev 1/2010: 111-147

Blanchard OJ, Landier A (2002) The perverse effects of partial labor market reform: Fixed duration contracts in France. Econ J 112: 214-244

Blanchard OJ, Summers L (1986) Hysteresis and the European unemployment problem In: NBER Macroeconomics annual. MIT Press, Cambridge. pp 15-77

Blanchard OJ, Tirole J (2003) Contours of employment protection reform. MIT Department of Economics Working Paper 03-35, Cambridge (Ma)

Boeri T (2011) Institutional reforms and dualism in European labor markets In: Ashenfelter O, Card D (eds) Handbook of labor economics vol. 4b, North Holland, Amsterdam. pp 1173-1236

Boeri T, Garibaldi P (2008) Un nuovo nontratto per tutti. Chiarelettere, Torino

Burda M, Hunt J (2011) What explains the German labor market miracle in the Great Recession? Brookings Pap Econ Act, Spring 42: 273-319

Cahuc P, Kramarz F (2004) De la précarité à la mobilité, vers une sécurité sociale professionnelle, Rapport pour le Ministre de l'Economie et des Finances. La documentation Française, Paris

Cahuc P, Postel-Vinay F (2002) Temporary jobs, employment protection and labor market performance. Labour Econ 9: 63-91

Carrasco R, Jimeno JF, Ortega AC (2011) The effect of immigration on the labor market performance of native-born workers: Some evidence for Spain. J Population Econ 21: 627-648

Casado JM, Fernandez-Vidaurreta C, Jimeno JF (2012) Labour market flows in the European Union. Boletín Económico, Banco de España, January: 91-101, Madrid

Conde Ruiz Jl, Felgueroso F, García Pérez JI (2011) Reforma laboral 2010: Una primera evaluación y propuestas de mejora. Revista de economía aplicada 19: 147-182

Costain J, Jimeno JF, Thomas C (2010) Employment fluctuations in a dual labor market. Banco de España Working Paper 1013, Madrid

Dolado J, Felgueroso F, Jansen M (2010) El conflicto entre la demanda de flexibilidad laboral y la resistencia a la reforma del mercado de trabajo en España. Pap Econ Española 124: 84-97

Dolado J, Garcia-Serrano C, Jimeno JF (2002) Drawing lessons from the boom of temporary jobs in Spain. Econ J 112: F270-F295

Dolado J, Ortigueira S, Stucchi R (2011) Does dual employment protection affect TFP? Evidence from Spanish manufacturing firms. Universidad Carlos III Economics Working Papers 11-37, Madrid

Duval R, Elmeskov J (2005) The effects of EMU on structural reforms in labour and product markets, OECD Economics Department Working Papers 438. OECD Publishing

European Commission (2011) Labour market developments in Europe, 2011. European economy 2/2011. European Commission, Luxembourg

García Pérez Jl, Osuna V (2011) The effects of introducing a single open-ended contract in the Spanish labour market. Universidad Pablo de Olavide, Mimeo

García Pérez Jl, Rebollo Sanz YF (2009) Do wage subsidies affect the subsequent employment stability of permanent workers? The case of Spain. Moneda Crédito 228: 65-102

Gavilán A, Hernández de Cos P, Jimeno JF, Rojas JA (2011) Fiscal policy, structural reforms and external imbalances: A quantitative evaluation for Spain. Banco de España Working Paper 1107, Madrid

Høj J, Galasso V, Nicoletti G, Dang T-T (2006) The political economy of structural reform. OECD Economics Department Working Paper 501, OECD Publishing

Ichino P, et al. (2009) Disegno di legge per la transizione a un regime di flexicurity, n. 1481. Senato Italiano, Rome International Monetary Fund (2010) World economic outlook. Rebalancing Growth. IMF, Washington DC

Jimeno JF, Thomas C (2011) Collective bargaining, firm heterogeneity and unemployment. Banco de España Working Paper 1131, Madrid

Jimeno JF, Toharia L (1996) Effort, absenteeism, and fixed term employment contracts. Rev Española Econ 13: 105-119

Lazear E (1990) Job security provisions and employment. Quart J Econ 105: 699-726

Lindbeck A, Snower DJ (1984) Involuntary unemployment as an insider-outsider dilemma. Institute for International Economic Studies Seminar Paper 309, Stockholm

Lindbeck, A, Snower DJ (1988) The insider-outsider theory of employment and unemployment. MIT Press, Cambridge 
Madera R (2012) Dual labor markets and productivity. CEMFI Master Thesis 1201. http://www.cemfi.es/ftp/mt/t1201.pdf Mortensen DT, Pissarides CA (1994) Job creation and job destruction in the theory of unemployment. Rev Econ Stud 61 : $397-415$

Saint-Paul G (1996) Dual labor markets. MIT Press, Cambridge

Saint-Paul, G (2000) The political economy of labour market institutions. Oxford University Press, Oxford

Saint-Paul, G (2002) Macroeconomic fluctuations and the timing of labour market reforms. CEPR Working Paper 3646, London

Venn D (2009) Legislation, Collective Bargaining and Enforcement: Updating the OECD Employment Protection Indicators, OECD Social, Employment and Migration Working Papers 89. OECD Publishing

Visser J (2011) ICTWSS: Database on institutional characteristics of trade unions, wage setting, state intervention and social pacts in 34 countries between 1960 and 2007. Vers. 3 Amsterdam Institute for Advanced Studies. (http://www. uva-aias.net/208)

doi:10.1186/2193-9012-1-4

Cite this article as: Bentolila et al:: Reforming an insider-outsider labor market: the Spanish experience. IZA Journal of European Labor Studies 2012 1:4.

\section{Submit your manuscript to a SpringerOpen ${ }^{\odot}$ journal and benefit from:}

- Convenient online submission

- Rigorous peer review

- Immediate publication on acceptance

- Open access: articles freely available online

- High visibility within the field

- Retaining the copyright to your article

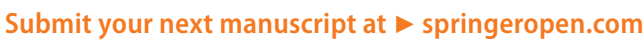

